\title{
Farm Households Food Demand and Its Determinants in Nigeria
}

\author{
F. M. Oluwatusin ${ }^{1 *}$, A. O. Adekunmi ${ }^{1}$, A. Ajiboye ${ }^{1}$, S. O. W. Toluwase ${ }^{1}$, \\ F. O. Osundare ${ }^{1}$ and K. A. Abdu-Raheem ${ }^{1}$ \\ ${ }^{1}$ Department of Agricultural Economics and Extension Services, Ekiti State University, \\ P.M.B. 5363, Ado-Ekiti, Nigeria.
}

\begin{abstract}
Authors' contributions
This research was carried out in collaboration among all authors. All authors designed the study and wrote the protocol. Author FMO performed the statistical analyses with interpretation. Author AOA wrote the first draft of the manuscript. Authors AA and SOWT managed the analyses of the study. Author FOO managed the literature searches. Author KAA revised the written manuscript. All authors read, contributed and approved the final version of the manuscript.

Article Information DOI: $10.9734 / A R R B / 2019 / v 34 i 430158$
Editor(s):
$\begin{array}{r}\text { (1) Paola Angelini, Department of Applied Biology, University of Perugia, Perugia, Italy. } \\ \text { Reviewers: } \\ \text { (1) David Conner, USA. } \\ \text { (2) Jorge Isaac Castro Bedriñana, Universidad Nacional del Centro del Perú, Peru. } \\ \text { Complete Peer review History: http://www.sdiarticle4.com/review-history/54844 }\end{array}$
\end{abstract}

Original Research Article

Received 06 December 2019

Accepted 11 February 2020

Published 17 February 2020

\section{ABSTRACT}

Aims: The study examined the farming households' food demand in Nigeria by, identifying the socio-economic characteristics of the farming households, assessing the monthly expenditure share of various categories of food in the total households' food budget, analyzing the expenditure elasticities of the food classes and examining the factors influencing food demand.

Methodology: A questionnaire was used as research instrument to elicit primary data from 120 farming households randomly selected through a multi-stage sampling method. The data analyses were done through the use of descriptive statistics and Quadratic Almost Ideal Demand System (QUAIDS) model.

Results: The results show that 61.7 percent of the household heads were men while the mean age was 45.7 years. Most $(92.5 \%)$ of the household heads were educated with mean household size of 7 persons and mean monthly income of $\mathrm{N19}, 435.20$. The analysis of average monthly expenditure share of various food classes demanded for by the households reveals that roots and tubers food class had the largest (48\%) share of households' total food expenditure while flesh foods and dairy 
products came last with just 2 percent. In addition, expenditure elasticities of the six classes of food considered indicate that demand for roots and tubers, starchy food, fruits and vegetables and fats and oil food classes were inelastic while that of Flesh foods and dairy products and protein grains were elastic. Also it was revealed that farm households with small household sizes consume more proteinous foods. The determinants that had the expected sign and cut across all food classes were the price of individual food category and household income.

Conclusion: The study analysed the farming households' food demand and its determinants and in order to improve the farm households' demand for food, it is recommended that policies to prevent upward or downward swings in the prices of foods in the economy should be put in place.

Keywords: Demand; food; farming; elasticities.

\section{INTRODUCTION}

Nigeria is Africa's most populous country with an estimated total population of about 195.9 million people [1] and one of the fastest growing economies [2]. Agricultural sector contributes about 21.2 percent to Nigeria's annual Gross Domestic Product (GDP) [3] and the main source of livelihood for over 70 percent of the populace. Food is a basic need for the existence of human beings. It is needed for the maintenance of good health and to improve productivity. The two main sources for human food requirements are food supply and food demand. Food supply refers to the physical access to food through production, while food demand is the economic access to food through market and exchange.

The level of demand and consumption of food can also be determined by five major factors which are income of the consumers, taste of the product, prices of the products and its substitutes and population level. Bennett's law states that as income increases, consumers are more likely to increase their demand for non-food products rather than the demand for food. Much emphasis has been placed on increasing food supplies, in the attempt to bridge the food supply demand gap in Nigeria without anything being done to manage the food demand. Farmers have to choose between the quality and quantity of food they consume and the ones they sell, because of the growing demand of food by the increasing population (2.59\% annually) and no appreciable increase in the agricultural productivity $(2.12 \%$ annually) [1].

Food demand is determined by factors at the national (aggregate), the intermediate, and the household (micro) level [4]. Aggregate-level determinants of food consumption include urbanization, population, per capita incomes and overall changes in lifestyle. Intermediate-level determinants include factors such as cultural changes that affect changes in tastes and preferences. Household level factors include households' socio-economic characteristics such as household size, age, income and sex, etc. Households therefore differ among themselves in food consumption and demand and in particular, in their response to changes in market situations.

Knowledge of the determinants of food demand is critical for informed policy making. However, in Nigeria, information on food demand among farm households is limited, thus restricting agricultural policymakers' ability to make sound food policy decisions. It is against this background that this study examined the farm households' food demand and its determinants by, specifically, identifying the socio-economic characteristics of the farming households; assessing the monthly expenditure share of various categories of food in the total households' food budget; analyzing the expenditure elasticities of the food classes and examining the factors influencing food demand among farming households in Nigeria.

\section{MATERIALS AND METHODS}

\subsection{Study Area}

The study was carried out in Ondo State, Nigeria. The state covers a land area of about $14,788.723$ square kilometers. The projected population of the state as at 2015 was $4,517,027$ [5]. The State is bounded in the North by Ekiti and Kogi States and in the South by the Atlantic Ocean. Ondo State is located entirely within the Tropics (Fig. 1). The tropical climate of the state has two seasons: Rainy season (AprilOctober) and dry season (November - March). The state temperature throughout the year is between $21^{\circ} \mathrm{C}$ and $29^{\circ} \mathrm{C}$ with relatively high humidity. The annual rainfall varies between $2,000 \mathrm{~mm}$ in the southern areas and 1,150 $\mathrm{mm}$ in the northern areas. The state has high forest zone (rain forest) in the south and 


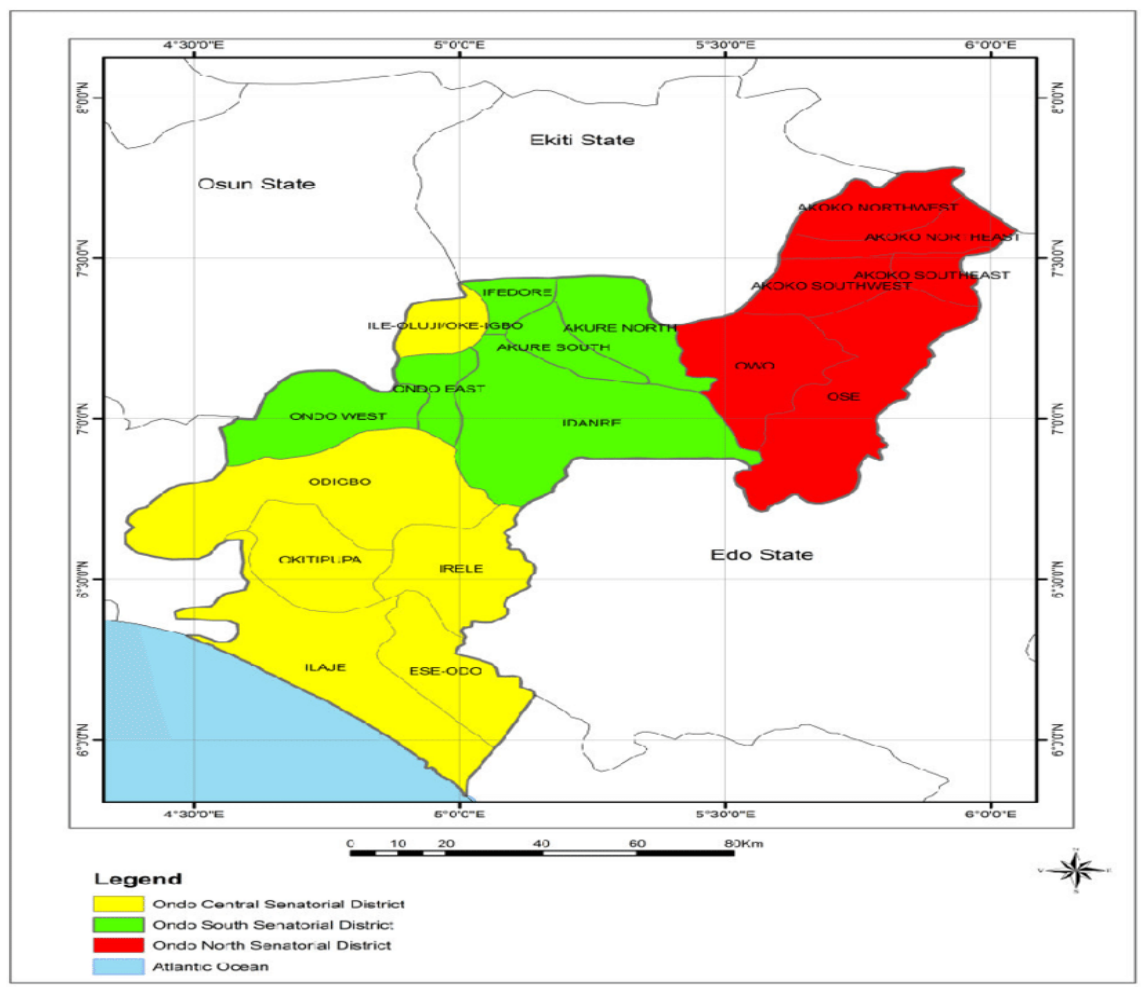

Fig. 1. Map of Ondo State

Source: Ondo State Ministry of Housing and Urban Development

sub-savannah forest in the northern fringe. The State's economy is basically agrarian with large scale production of the followings: cocoa, palm produce, timber and rubber, maize, yam and cassava.

\subsection{Sources of Data}

Primary and secondary data were extensively used. The primary data were gotten with the use of interview schedule and questionnaire that was administered on Ondo State farming households through the help of trained enumerators. Other sources of data were published materials and journals.

\subsection{Sampling Techniques}

A multi-stage random sampling method was used to select 120 farming households from the list of the farming households provided by the Ondo State Ministry of Agriculture. The first stage involved the random selection of two (2) Local Government Areas (LGAs) from each of the three Senatorial Districts while at the second stage, two (2) communities from each LGA were randomly selected and the final stage involved the random selection of 10 farming households from each of the communities selected.

\subsection{Analytical Techniques}

Descriptive statistics and Quadratic Almost Ideal Demand System (QUAIDS) model were used to analyze the data generated.

The Quadratic Almost Ideal Demand System (QUAIDS) model used in the study is specified as follows:

$$
\begin{gathered}
w t_{i}=\alpha_{i}+\sum_{i=1}^{j} \gamma_{I j} \operatorname{lnp} p_{i}+\beta_{i} \ln \left[\frac{m}{a(p)}\right]+\frac{\lambda_{i}}{b(p)}\left\{\ln \left[\frac{m}{a(p)}\right]\right\}^{2} \\
+\sum_{s=1}^{L} \delta_{i s} Z_{i s}+\varepsilon_{i}
\end{gathered}
$$

Where:

$w t_{i}=$ household's expenditure share of $i^{\text {th }}$ food class, $\mathrm{i}=1,2,3,4,5$, and 6

$\mathrm{wt}_{1}=$ household's expenditure share of roots and tubers foods (e.g yam, cassava, etc.)

$\mathrm{wt}_{2}=$ household's expenditure share of starchy grains foods (e.g rice, maize, etc.) 
$w t_{3}=$ household's expenditure share of fruits and vegetables food (e.g banana, onion, tomatoes, etc.)

$w_{4}=$ household's expenditure share of flesh foods and dairy products (e.g meat, fish, chicken, milk, etc.)

$w_{5}=$ household's expenditure share of fats and oil food (e.g palm oil, ground nut oil, etc.)

$w_{6}=$ household's expenditure share of protein grains food (e.g beans, nuts, etc.)

$\mathrm{p}_{\mathrm{i}}=$ price of food $\mathrm{i}^{\mathrm{th}}(\mathrm{N} /$ grain equivalent $\mathrm{kg})$, for $\mathrm{i}=1,2,3,4,5$ and 6

$\mathrm{p}_{1}=$ price of roots and tubers foods (PRTF) $(\mathrm{A} / \mathrm{kg})$

$\mathrm{p}_{2}=$ price of starchy grains foods (PSGF) $(\mathrm{N} / \mathrm{kg})$

$\mathrm{p}_{3}=$ price of fruits and vegetables foods (PFVF) $(\mathrm{A} / \mathrm{kg})$

$\mathrm{p}_{4}=$ price of flesh foods and dairy products (PFFDP) ( $\mathbb{N} / \mathrm{kg})$

$\mathrm{p}_{5}=$ price of fats and oil food (PFOF) ( $\mathrm{N} /$ litre $)$

$\mathrm{p}_{6}=$ price of protein grains food (PPGF) ( $\left.\mathbb{N} / \mathrm{kg}\right)$

$\mathrm{m}=$ household's total food expenditure (HTFE) (A/ week)

$\mathrm{Z}_{\mathrm{i}}=$ household's socioeconomic characteristics

$Z_{1}=$ household head age (AGE) (year)

$z_{2}=$ household Size (number)

$\mathrm{z}_{3}=$ household head educational level (HHEL) (year)

$\mathrm{Z}_{4}=$ household income $(\mathbb{N})$

$\varepsilon_{\mathrm{i}}=$ error term

The price index $[a(p)]$ is used to deflate total expenditure and $\ln a(p)$ a transcendental logarithm function is defined as:

$\ln a(p)=\alpha_{0}+\sum_{i=1}^{k} \alpha_{i} \ln p_{i}+\frac{1}{2} \sum_{i=1}^{k} \sum_{j=1}^{k} \gamma_{i j} \ln p_{i} \ln p_{j}$

Also, $b(p)$ is the simple Cobb-Douglas price aggregator, defined as:

$b(p)=\prod_{i=1}^{k} p_{i} \beta_{i}$

In addition, the household's expenditure share of $i^{\text {th }}$ food class $\left(w t_{i}\right)$ is defined as:

$w t_{i}=\frac{p_{i} q_{i}}{m}$

Where $q_{i}$ is the quantity of food $i$ purchased. Other variables are as earlier defined.

When the first derivative of equation 1 is taken with respect to expenditure and prices then we have:

$$
\begin{aligned}
& \mu_{i}=\frac{\partial w t_{i}}{\partial \ln m}=\beta_{i}+\frac{2 \lambda_{i}}{b(p)}\left\{\ln \left[\frac{m}{a(p)}\right]\right\} \\
& \mu_{i j}=\frac{\partial w t_{i}}{\partial \ln p_{j}}=\gamma_{i j}-\mu_{i}\left(\alpha_{j}+\sum_{i} \gamma_{j k} \ln p_{k}\right)-\frac{\lambda_{i} \beta_{i}}{b(p)}\left\{\ln \left[\frac{m}{a(p)}\right]\right\}^{2}
\end{aligned}
$$

The expenditure elasticities for the study are derived by equation 7 :

$e_{i}=1+\frac{\mu_{i}}{w t_{i}}$

\section{RESULTS AND DISCUSSION}

\subsection{Respondents Socio-economics Characteristics}

Table 1 shows the description of the socioeconomic characteristics of the farmers.

Most $(61.7 \%)$ of the farm household heads were males while 38.3 percent were females. This shows that men are more involved in farming activities than their women counterparts in the study area. This may be due to the hard monotonous routine work in agriculture. This is in line with the findings of Ashagidigbi et al. [6] and Amao [7] who observed that males dominate farming activities. The mean age of the household heads was 45.7 years while those between 31 and 50 years were 43.3 percent. Those between 51 and 70 years were 30.8 percent and 17.5 percent were above the age of 70 years. The results indicate that the farmers are still in their active age and this contradicts the report of Adeyonu et al. [8] who reported evidence of ageing farming population in Nigeria. Over average of the farmers were married. This implies that the household demand for food is likely to be high. In addition, 92.5 percent were educated in formal institutions. This means that most of the farm household heads can read and write. This result is not in agreement with that of Otunaiya et al. [9] report that educational level among the farming households is low.

Also, those who practiced farming primarily were 37.5 percent, while 22.5 percent were primarily involved in artisanship. Just 20 percent took trading as their primary occupation and civil servants among them were also 20 percent. The farmers had relatively high household size of mean 7 persons. It has been reported that large household size will enable farmers to use family labour in the areas of farming activities that require labour intensive techniques [10]. The

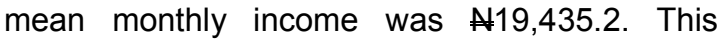
finding presents the farm households in the study area as low income earners. 
Table 1. Socio-economic characteristics of respondents

\begin{tabular}{|c|c|c|c|}
\hline Socioeconomic characteristics & Frequency $(\mathrm{N}=120)$ & Percentage & Mean \\
\hline \multicolumn{4}{|l|}{ Gender } \\
\hline Male & 14 & 61.7 & \\
\hline Female & 46 & 38.3 & \\
\hline Age & & & 45.7 \\
\hline$\leq 30$ & 10 & 8.3 & \\
\hline $31-50$ & 52 & 43.3 & \\
\hline $51-70$ & 37 & 30.8 & \\
\hline$>70$ & 21 & 17.5 & \\
\hline \multicolumn{4}{|l|}{ Marital status } \\
\hline Single & 7 & 5.8 & \\
\hline Married & 64 & 53.3 & \\
\hline Widowed & 20 & 16.7 & \\
\hline Divorced & 17 & 14.2 & \\
\hline Separated & 12 & 10.0 & \\
\hline \multicolumn{4}{|l|}{ Educational level } \\
\hline No formal education & 9 & 7.5 & \\
\hline Adult education & 13 & 10.8 & \\
\hline Primary education & 18 & 15.0 & \\
\hline Secondary education & 52 & 43.3 & \\
\hline Tertiary education & 28 & 23.4 & \\
\hline \multicolumn{4}{|l|}{ Primary occupation } \\
\hline Farmer & 45 & 37.5 & \\
\hline Artisan & 27 & 22.5 & \\
\hline Trader & 24 & 20.0 & \\
\hline Civil servant & 24 & 20.0 & \\
\hline Household size & & & 7.3 \\
\hline$\leq 5$ & 19 & 15.8 & \\
\hline $6-10$ & 35 & 37.5 & \\
\hline $10-15$ & 45 & 29.2 & \\
\hline$>15$ & 21 & 17.5 & \\
\hline Monthly income (N) & & & \#19,435.2 \\
\hline$\leq 20,000$ & 52 & 43.3 & \\
\hline $20,001-40,000$ & 41 & 34.2 & \\
\hline $40,001-60,000$ & 17 & 14.2 & \\
\hline$>60,000$ & 10 & 8.3 & \\
\hline
\end{tabular}

\subsection{Average Monthly Expenditure Share of Various Food Classes}

Table 2 reveals the average monthly expenditure share of various food classes among the farm households in the study area. It shows that the largest (48\%) share of households' total food expenditures went to roots and tubers foods class and this was followed by starchy grains with 23 percent, while flesh foods and dairy products came last with 2 percent. The result is not in line with the findings of Otunaiya et al. [9] where among the rural farming households in Ogun State, grains food class has the highest share of the households' food expenditure. The above results show that more roots and tubers crops are consumed in the study area. This might be due to availability and low prices of these food items in the area. Also some of these crops are cultivated by the farmers.

Table 2. Respondents' average monthly expenditure share of food classes

\begin{tabular}{lll}
\hline Food classes & Mean & $\begin{array}{l}\text { Std. } \\
\text { deviation }\end{array}$ \\
\hline Roots and tubers & 0.48 & 0.25 \\
Starchy grains & 0.23 & 0.08 \\
Fruits and vegetables & 0.14 & 0.05 \\
Flesh foods and dairy & 0.02 & 0.01 \\
products & & \\
Fats and oil & 0.10 & 0.03 \\
Protein grains & 0.03 & 0.02 \\
\hline
\end{tabular}




\subsection{Expenditure Elasticities of Food Classes}

Table 3 shows the expenditure elasticities of the six classes of food considered. The results reveal that all the classes of food coefficients were positively and significantly different from zero at one percent level of significance with the exception of the coefficient of fruits and vegetable that was significant at five percent. The expenditure elasticities of roots and tubers (0.573), starchy food (0.210), fruits and vegetables (0.974) and fats and oil (0.063) food classes were inelastic while that of flesh foods and dairy products (1.541) and protein grains (1.124) were elastic. The expenditure elasticity for fats and oil was highly inelastic because vegetable oil is found nearly in all meals of farm households in the area. The results show that all the classes of food considered were normal goods. In the study area, roots and tubers, starchy food, fruits and vegetables and fats and oil food classes are necessities, that is they are necessary foods to the farm households, while flesh foods and dairy products and protein grains are luxuries. The result seems plausible because the farm households in the study area are low income earners. Demand for any good is inelastic if it does not respond much to its price changes and elastic if demand changes a lot when it price changes. The findings corroborate the results of Abdullahi [11], Okoruwa and Adebayo [12], Ashagidigbi et al. [6], Otunaiya et al. [9].

\section{Table 3. Expenditure elasticities of food} classes

\begin{tabular}{ll}
\hline $\begin{array}{l}\text { Food } \\
\text { classes }\end{array}$ & $\begin{array}{l}\text { Expenditure } \\
\text { elasticities }\end{array}$ \\
\hline Roots and tubers & $0.573^{* * *}(0.209)$ \\
Starchy grains & $0.210^{* * *}(0.066)$ \\
Fruits and vegetables & $0.974^{* *}(0.384)$ \\
Flesh foods and dairy & $1.541^{* * *}(0.494)$ \\
products & \\
Fats and oil & $0.063^{* * *}(0.019)$ \\
Protein grains & $1.124^{* * *}(0.272)$ \\
\hline s*and ${ }^{* * *}$ means significant at $5 \%$ and $1 \%$ levels of \\
significance respectively. Figures in parentheses are \\
\multicolumn{2}{r}{ standard errors }
\end{tabular}

\subsection{Factors Determining the Demand for Food among Farming Households}

Table 4 shows the estimated coefficients of the QUAIDS model. The results show that 63,71 , $55,60,59$ and 57 percents variations in the expenditure share of starchy grains, fruits and vegetables, flesh foods and dairy products, fats and oil and protein grains respectively were explained by the independent variables included in the model. According to Table 4, the price of roots and tubers food class (PRTF) had negative and significant relationship with the shares of roots and tubers (1\%), flesh foods and dairy products $(1 \%)$ and fats and oil $(10 \%)$ food classes. This implies that as the price of roots and tubers increases, the shares of roots and tubers, flesh foods and dairy products and fats and oil food classes in the household total budget reduce. Also, the price of roots and tubers food class was positively and significantly related to the share of starchy grains. This indicates that as the price of roots and tubers increases (reduces), the share of starchy grains in the household expenditure increase (reduces).

Furthermore, the price of starchy grains (PSGF) was significantly and negatively related to the expenditure shares of starchy grains $(1 \%)$ and fats and oil $(1 \%)$ food classes. The price is positively and significantly $(10 \%)$ related to roots and tubers food class. This implies that the shares of the two food classes in the household expenditure on foods reduce as the price of starchy grains increases and vice versa. The price of fruits and vegetables (PFVF) had a negative and significant relationship with the share of fruits and vegetables at 1 percent level of significance. This shows that the share of fruits and vegetables in the household expenditure on food goes down as its prices increases. Also the results in Table 4 indicates that the price of flesh foods and dairy products (PFFDP) was negatively and significantly related to its share and that of fats and oil share in the household expenditure on foods at 10 percent and 5 percent respectively. This signifies an inverse relationship. But this price was positively and significantly related to the share of starchy grains at 10 percent, a direct relationship.

In addition, the price of fats and oil (PFOF) had a negative and significant effect at 10 percent and 1 percent on the shares of both roots and tubers and fats and oil in the household expenditure on foods respectively. This means that, the higher the price of fats and oil, the lower will be the shares of both roots and tubers and fats and oil in the household expenditure budget. Also the price of fats and oil exhibited positive and significant relationship at 10 percent with starchy grains and flesh foods and dairy products shares in the budget. This is an indication that the 
household will increase the shares of starchy grains and flesh foods and dairy products in its expenditure budget when the price of fats and oil increases. In Table 4, the price of protein grains (PPGF) was negative and significantly different from zero at 5 percent level of significance only with the share of protein grains in the household expenditure budget. This signifies that less of protein grains food class appears in the household expenditure budget as its price increases and vice versa.

The age of the household head (AGE) had positive and significant relationship at 5 percent and 1 percent levels of significance with the shares of roots and tubers and starchy grains respectively in the household expenditure. But negatively and significantly, at 10 percent, related to both flesh foods and dairy products and protein grains shares. This means that more of roots and tubers and starchy grains food classes would be found in the household expenditure budget as the household head grows older. This shows that less of carbohydrate and more of the proteinous food classes are found in the household budget of the young household heads compared with their aged counterparts.

In addition, according to Table 4, household size was positively and significantly at 5 percent and 10 percent related to the shares of roots and tubers and starchy grains food classes respectively in the household expenditure budget. It implies that, as the household size increases, the shares of these food classes in the household expenditure budget increases. This may happen because, most of the time, increase in household size leads to increase in per capita household expenditure and hence increase in the consumption of food classes that are not expensive. Also household size had negative and significant relationship at 5 percent level of significance with the share of flesh foods and dairy products. This shows that as the household size increases, less of this food class (flesh foods and dairy products) will be found in the household expenditure budget. This is common among the poor households. Less expensive food classes are found in their baskets of food as their household size increases.

Table 4. Determinants of farm households' food demand

\begin{tabular}{|c|c|c|c|c|c|c|}
\hline Variables & $\begin{array}{l}\text { Roots } \\
\text { and } \\
\text { tubers }\end{array}$ & $\begin{array}{l}\text { Starchy } \\
\text { grains }\end{array}$ & $\begin{array}{l}\text { Fruits } \\
\text { and } \\
\text { vegetables }\end{array}$ & $\begin{array}{l}\text { Flesh foods } \\
\text { and } \\
\text { dairy } \\
\text { products }\end{array}$ & $\begin{array}{l}\text { Fats } \\
\text { and } \\
\text { oil }\end{array}$ & $\begin{array}{l}\text { Protein } \\
\text { grains }\end{array}$ \\
\hline (Constant) & $\begin{array}{l}0.636^{* *} \\
(2.541)\end{array}$ & $\begin{array}{l}0.275^{* *} \\
(1.991)\end{array}$ & $\begin{array}{l}0.871^{\star \star *} \\
(4.196)\end{array}$ & $\begin{array}{l}0.294^{*} \\
(1.721)\end{array}$ & $\begin{array}{l}0.723 \\
(1.210)\end{array}$ & $\begin{array}{l}0.328 \\
(1.153)\end{array}$ \\
\hline PRTF & $\begin{array}{l}-0.582^{* * *} \\
(3.206)\end{array}$ & $\begin{array}{l}0.374^{* *} \\
(2.503)\end{array}$ & $\begin{array}{l}0.362 \\
(1.374)\end{array}$ & $\begin{array}{l}-0.338^{* * *} \\
(2.750)\end{array}$ & $\begin{array}{l}-0.529^{\star} \\
(1.726)\end{array}$ & $\begin{array}{l}0.043 \\
(1.256)\end{array}$ \\
\hline PSGF & $\begin{array}{l}0.532^{*} \\
(1.711)\end{array}$ & $\begin{array}{l}-0.413^{* * *} \\
(3.957)\end{array}$ & $\begin{array}{l}0.382 \\
(1.516)\end{array}$ & $\begin{array}{l}0.671 \\
(1.226)\end{array}$ & $\begin{array}{l}-0.509^{* * *} \\
(2.710)\end{array}$ & $\begin{array}{l}-0.218 \\
(1.842)\end{array}$ \\
\hline PFVF & $\begin{array}{l}0.392 \\
(1.523)\end{array}$ & $\begin{array}{l}0.712 \\
(0.791)\end{array}$ & $\begin{array}{l}-0.562^{* * *} \\
(5.218)\end{array}$ & $\begin{array}{l}0.630 \\
(1.495)\end{array}$ & $\begin{array}{l}0.391 \\
(0.195)\end{array}$ & $\begin{array}{l}0.438 \\
(1.612)\end{array}$ \\
\hline PFFDP & $\begin{array}{l}-0.721 \\
(1.038)\end{array}$ & $\begin{array}{l}0.629^{*} \\
(1.715)\end{array}$ & $\begin{array}{l}0.629 \\
(0.938)\end{array}$ & $\begin{array}{l}-0.956^{*} \\
(2.511)\end{array}$ & $\begin{array}{l}-0.865^{* *} \\
(1.98)\end{array}$ & $\begin{array}{l}0.729 \\
(1.531)\end{array}$ \\
\hline PFOF & $\begin{array}{l}-0.702^{*} \\
(1.791)\end{array}$ & $\begin{array}{l}0.964^{*} \\
(1.829)\end{array}$ & $\begin{array}{l}0.721 \\
(0.529)\end{array}$ & $\begin{array}{l}0.540^{*} \\
(1.787)\end{array}$ & $\begin{array}{l}-0.925^{\star * *} \\
(3.294)\end{array}$ & $\begin{array}{l}0.770 \\
(1.204)\end{array}$ \\
\hline PPGF & $\begin{array}{l}0.672 \\
(1.420)\end{array}$ & $\begin{array}{l}-0.783 \\
(1.223)\end{array}$ & $\begin{array}{l}0.632 \\
(0.628)\end{array}$ & $\begin{array}{l}0.821 \\
(0.524)\end{array}$ & $\begin{array}{l}0.672 \\
(1.621)\end{array}$ & $\begin{array}{l}-0.931^{* *} \\
(2.618)\end{array}$ \\
\hline AGE & $\begin{array}{l}0.624^{* *} \\
(2.123)\end{array}$ & $\begin{array}{l}0.853^{\star * *} \\
(4.81)\end{array}$ & $\begin{array}{l}0.826 \\
(1.062)\end{array}$ & $\begin{array}{l}-0.925^{*} \\
(1.710)\end{array}$ & $\begin{array}{l}0.382^{*} \\
(1.861)\end{array}$ & $\begin{array}{l}-0.720^{*} \\
(1.841)\end{array}$ \\
\hline Household size & $\begin{array}{l}0.829^{* *} \\
(2.463)\end{array}$ & $\begin{array}{l}0.728^{*} \\
(1.772)\end{array}$ & $\begin{array}{l}-0.349 \\
(1.476)\end{array}$ & $\begin{array}{l}-0.826^{\star *} \\
(2.037)\end{array}$ & $\begin{array}{l}0.062 \\
(0.727)\end{array}$ & $\begin{array}{l}-0.037 \\
(1.238)\end{array}$ \\
\hline HHEL & $\begin{array}{l}-0.725^{\star *} \\
(2.078)\end{array}$ & $\begin{array}{l}-0.372 \\
(0.669)\end{array}$ & $\begin{array}{l}0.820 \\
(1.382)\end{array}$ & $\begin{array}{l}0.726^{\star * *} \\
(3.821)\end{array}$ & $\begin{array}{l}0.725 \\
(1.264)\end{array}$ & $\begin{array}{l}0.281^{* *} \\
(2.541)\end{array}$ \\
\hline $\begin{array}{l}\text { Household } \\
\text { income } \\
\mathrm{R}^{2}\end{array}$ & $\begin{array}{l}-0.492^{* *} \\
(2.510) \\
0.631\end{array}$ & $\begin{array}{l}-0.239^{*} \\
(1.927) \\
0.711\end{array}$ & $\begin{array}{l}0.926^{*} \\
(1.742) \\
0.549\end{array}$ & $\begin{array}{l}0.825^{\star * *} \\
(4.733) \\
0.601\end{array}$ & $\begin{array}{l}0.284^{\star * *} \\
(3.821) \\
0.588\end{array}$ & $\begin{array}{l}0.283^{* *} \\
(2.501) \\
0.571\end{array}$ \\
\hline
\end{tabular}


Furthermore, Table 4 results show that, the household head educational level (HHEL) affected the shares of flesh foods and dairy products and protein grains in the household expenditure budget positively and significantly at 1 percent and 5 percent respectively. This implies that as the number of years the household head spent in school increases, the shares of flesh foods and dairy products and protein grains in the household expenditure budget increases. Educated farm household head knows better the importance of proteinous foods. But the household head educational level had a negative and significant relationship with the share of roots and tubers food class in the farm household expenditure budget at 5 percent level of significance. This shows that less of carbohydrate foods are consumed as the level of education of farm household head increases.

Moreover, household income displayed a positive and significant relationship at 10,1 , and 5 percents with the shares of fruits and vegetables, flesh foods and dairy products and protein grains respectively in the farm household expenditure budget. But household income had negative and significant effect at 5, 10 and 1 percents on the shares of roots and tubers, starchy grains and fats and oil foods respectively in the household food expenditure budget. This is an indication that the higher the household income, the more the shares of expensive food items (proteinous foods) and the less the shares of the less expensive food items (carbohydrate foods) in the household food expenditure budget.

\section{CONCLUSION AND RECOMMENDA- TIONS}

The study investigated the demand for some food classes among farming households in Nigeria. Specifically, it examined the socioeconomics characteristics of the farming households and looked at the monthly expenditure share of food classes such as; roots and tubers, starchy grains, fruits and vegetables, flesh foods and dairy products, fats and oil and protein grains. Also it investigated the expenditure elasticities of food classes and determined the factors influencing demand for food among the farming households in the study area. Both descriptive statistics and QUAIDS model were used to analyze the data collected.

It was revealed that roots and tubers food class took the largest share of the farm households' food expenditure and this was followed by starchy grains food class. The least share went to flesh foods and dairy products food class. Analysis of expenditure elasticities showed that all the food classes were normal goods. Demand for roots and tubers, starchy food, fruits and vegetables and fats and oil food classes were inelastic while that of Flesh foods and dairy products and protein grains were elastic. The determinants that had the expected sign and cut across all food classes were the price of individual food category and household income. The results show that farm households with large household sizes consumed more carbohydrate than proteinous foods while those with smaller household sizes consumed less carbohydrate and more proteinous foods. Based on the findings of this study, it is hereby suggested that policy geared towards consumption of more proteinous food by the farming households should be put in place. Also, in order to prevent upward or downward swings in the prices of foods in the economy, prices of foods should be regulated by the government through formulation of price policies. This will go a long way to improve the demand for food especially among the low income earners of the society. In addition, credit at one digit interest rate should be extended to the farming households in order to increase agricultural production and farm household income.

\section{COMPETING INTERESTS}

Authors have declared that no competing interests exist.

\section{REFERENCES}

1. World Bank. World Bank annual report; 2018.

2. National Bureau of Statistics (NBS). National BIM Report of the NBS; 2017.

3. Statista. Nigeria: Distribution of gross domestic product (GDP) across economic sectors from 2008 to 2018. Statista Company, Hamburg, Germany; 2019.

4. Afolabi JA. Analysis of loan repayment among small Scale farmers in Oyo State, Nigeria. Journal Social Science. 2010; 22(2):115-119.

5. Ondo State Research and Statistics Department, Ministry of Economic Planning and Budget. Demograghic and vital statistics of Ondo State; 2015.

6. Ashagidigbi WM, Yusuf SA, Okoruwa VO. Determinants of households' food demand in Nigeria. World Rural Observe. 2012;4(4):17-28. 
7. Amao JO. Determinants of protein consumption among households in Ila Local Government area of Osun State, Nigeria. Middle-East Journal of Scientific Research. 2013;15(10):1401-1410.

8. Adeyonu AG, Oni OA, Okoruwa VO, Omonona BT. Seasonality in poverty level of rural farming households in Oyo State, Nigeria. ARPN Journal of Agricultural and Biological Science. 2012;7(8):570-575.

9. Otunaiya AO, Adeyonu AG, Ajiboye BO. Determinants of food demand among rural farming households in Ogun State, Nigeria. Ibadan Journal of Agricultural Research. 2016;12(1):1-11.

10. Sonaiya EB. Small poultry holdings, the family and community development ethology, ethics and self interest. In Livestock, Community and Environment, Proceedings $10^{\text {th }}$ International Conference of the Association of Institutions of Tropical Veterinary Medicine, AITVM, Copenhagen, Denmark. 2001;20-23.

11. Abdullahi A. Household demand for food in Switzerland. A quadratic almost ideal demand system. Department of Agricultural Economics, Swiss Federal Institute of Technology, Sonneggstrasse 33, 8092 Zurich, Switzerland. 2001; 85-92.

12. Okoruwa VO, Adebayo EA. Household food demand analysis in Adamawa State, Nigeria. Global Journal of Agricultural Sciences. 2008;5(2):109-115.

(c) 2019 Oluwatusin et al.; This is an Open Access article distributed under the terms of the Creative Commons Attribution License (http://creativecommons.org/licenses/by/4.0), which permits unrestricted use, distribution, and reproduction in any medium, provided the original work is properly cited. 